SOLUSI : Jurnal Ilmiah Bidang Ilmu Ekonomi Vol. 19, No. 2 April 2021, Hal 1-14
Fakultas Ekonomi Universitas Semarang

P-ISSN : 1412-5331, E-ISSN : 2716-2532

\title{
Pengaruh Self Efficacy dan Motivasi terhadap Prestasi Kerja Penyuluh Keluarga Berencana di Kabupaten Temanggung dengan Kepuasan Kerja sebagai Variabel Intervening
}

\author{
Wahyuningsih ${ }^{1}$, Fitri Lukiastuti ${ }^{2}$ \\ ${ }^{1}$ Fakultas Ekonomi, Stie Bank BPD, Kota Semarang, Indonesia \\ ${ }^{2}$ Fakultas Ekonomi, Stie Bank BPD, Kota Semarang, Indonesia
}

\section{INFO ARTIKEI}

Proses Artikel

Dikirim :

Diterima:

Dipublikasikan: April 2021

\begin{abstract}
ABSTRAK
Penyuluh Keluarga Berencana bertanggung jawab melakukan kegiatan penyuluhan, pelayanan, penggerakan, evaluasi, dan pengembangan Program Keluarga Berencana Nasional. Namun jumlah mereka terbatas, sementara wilayah yang menjadi tanggung jawabnya sangat luas. Oleh karena itu penelitian ini menguji pengaruh self efficacy dan motivasi terhadap prestasi kerja Penyuluh Keluarga Berencana di Kabupaten Temanggung dengan kepuasan kerja sebagai variabel intervening. Populasi dalam penelitian ini adalah semua Penyuluh Keluarga Berencana sejumlah 43 orang. Teknik yang digunakan adalah sampel jenuh, dimana semua populasi menjadi sampel. Data yang digunakan adalah data primer dan sekunder, selanjutnya dilakukan analisis jalur dengan bantuan SPSS 20 dan sobel test untuk uji mediasi. Hasil analisis menunjukkan bahwa self efficacytidak berpengaruh terhadap kepuasan kerja dan juga prestasi kerja. Motivasi berpengaruh positif dan signifikan terhadap kepuasan kerja dan prestasi kerja. Kepuasan kerja tidak berpengaruh terhadap prestasi kerja. Kepuasan kerja tidak memediasi pengaruh self efficacy dan motivasi terhadap prestasi kerja.
\end{abstract}

Kata Kunci :

self efficacy, motivasi, kepuasan kerja, prestasi kerja . 


\section{PENDAHULUAN}

Variabel kependudukan sangat erat kaitannya dengan pembangunan berkelanjutan (sustainable development goals). Definisi pembangunan berkelanjutan menurut PBB, adalah pembangunan yang dilakukan secara seimbang dengan memperhatikan daya dukung dan daya tampung lingkungan saat ini serta menjamin tercukupinya kebutuhan bagi generasi mendatang.

Undang-Undang Nomor 52 Tahun 2009 tentang Perkembangan Kependudukan dan Pembangunan Keluarga, mengamanatkan bahwa penduduk harus menjadi fokus dalam pembangunan berkelanjutan di Indonesia. Saat membahas tentang integrasi penduduk dengan pembangunan, ada dua hal pokok yang perlu diperhatikan,yaitu: 1) penduduk sebagai objek pembangunan;dan2) penduduk sebagai subjek pembangunan. Untuk itu diperlukan upaya pemberdayaan untuk menyadarkan hak dan meningkatkan kapasitas penduduk dalam pembangunan. Hal ini menyangkut pembangunan sumber daya manusia yang berkualitas (Renstra BKKBN 2015-2019, hal.1).

Indonesia menduduki peringkat ke-4 dengan jumlah pendudukterbanyak sedunia, setelah Cina, India, dan Amerika Serikat. Berdasarkan data BPS, Indonesia mengalami kemandegan total fertility rate (TFR) sejak periode 2002 sampai 2012 pada angka 2,6 anak per wanita. Laju Pertumbuhan Penduduk (LPP) per tahun juga masih lebih tinggi dari harapan, yaitu 1,49 persen per tahun. Oleh karena itu Pemerintah Indonesia masih terus berjuang menurunkan TFR melalui program keluarga berencana (Jurnal Keluarga Edisi Kelima, 2017).

Berdasarkan Renstra 2018-2023Dinas Pengendalian Penduduk, Keluarga Berencana, Pemberdayaan Perempuan, dan Perlindungan Anak (DPPKBPPPA) Kabupaten Temanggung, capaian indikator kinerja yang mendukung sasaran strategis nasional maupun provinsi adalah sebagai berikut: 1) TFR 0,88; 2) CPR 83,27;3)persentase angka ketidak-berlangsungan KB 7,78; 4) unmet need 5,59;5) persentase peserta KB Aktif MKJP 48,72; dan 6) jumlah peserta KB Aktif 83,27 (Renstra DPPKBPPPA 2019-2023).Dari data tersebut menunjukkan capaian Kabupaten Temanggung di atas Provinsi Jawa Tengah dan Nasional.

Meskipun capaian Indikator Kinerja Daerah (IKD) di atas provinsi dan nasional, namun dalam dokumen Evaluasi Rencana Pembangunan Jangka Menengah Daerah (RPJMD) tahun 2017, masih ditemukan permasalahan terkait Bidang Pengendalian Penduduk dan Keluarga Berencana, yaitu: 1) melemahnya daya dukung dan kemampuan penggerak program KB di masyarakat karena jumlah tenaga PLKB yang masih belum memenuhi standar kebutuhan; 2) Belum optimalnya peran Institusi Masyarakat Pedesaan (IMP) dalam mendukung program KB, perlu melibatkan relawan program KB; 3) Terbatasnya penguatan modal bagi kelompok Usaha Peningkatan Pendapatan Keluarga Sejahtera (UPPKS), sehingga menjadi kelompok yang kurang berkembang; 4) masih rendahnya partisipasi KB laki-laki; dan 5) Masih adanya perempuan menikah dibawah usia 20 tahun (Evaluasi RPJMD 2017).

Rasio PLKB atau Penyuluh Keluarga Berencana per desa/kelurahan, dimana dari target 1:2 pada akhir 2018, tercapai 1:6,72. Trend capaian selama periode 2015-2018 cenderung stagnan bahkan menurun dari 1:6 menjadi 1: 6,72. Kondisi tersebut menunjukkan bahwa wilayah yang harus diampu oleh seorang PLKB/PKB mencapai 6-7 desa/kelurahan. Capaian ini menurun dibandingkan tahun awal RPJMD dimana rasio PLKB mencapai 1:5. Capaian selama periode 2014-2018 terkait rasio PLKB/PKB perdesa/kelurahan dapat dilihat pada tabel berikut. 
Tabel 1. Capaian Rasio PKB

Kabupaten Temanggung

Tahun 2014-2018

\begin{tabular}{|l|l|l|l|}
\hline IKD & Tahun & Target & Capaian \\
\hline & & & \\
\hline Rasio & 2014 & $1: 5$ & $1: 5$ \\
\cline { 2 - 4 } $\begin{array}{l}\text { PLKB/PKB } \\
\text { per desa/ } \\
\text { kelurahan }\end{array}$ & 2015 & $1: 4$ & $1: 5$ \\
\cline { 2 - 4 } & 2016 & $1: 4$ & $1: 6$ \\
\cline { 2 - 4 } & 2017 & $1: 4$ & $1: 6$ \\
\cline { 2 - 4 } & 2018 & $1: 2$ & $1: 6,72$ \\
\hline
\end{tabular}

Sumber: Evaluasi RPJMD 2017, diolah

PKB adalah ASN yang memenuhi kualifikasi dan standar kompetensi serta mendapatkan tugas, tanggung jawab, wewenang, dan hak secara penuh dari pejabat yang berwenang untuk melaksanakan kegiatan penyuluhan, pelayanan, penggerakan, dan pengembangan program KKBPK. Adapun program KKBPK sendiri merupakan usaha yang terencana untuk menciptakan keluarga berkualitas dan penduduk tumbuh seimbang melalui pengaturan kehamilan, mengatur kelahiran anak, serta jarak dan usia ideal melahirkan.

Jumlah PKB/PLKB di Jawa Tengah 1.708 orang dengan total wilayah binaan 8.566 desa. Dengan demikian rasio petugas lapangan adalah 1:5. Dan pada tahun 2019 ini ada 101 orang PKB yang pensiun. Kondisi ini menjadi semakin tidak ideal. Mengingat beban kerja dan luas wilayah yang harus diampu oleh PLKB yang tidak ideal, maka ada beberapa kemungkinan timbulnya permasalahan antara lain: cakupan pelayanan ke masyarakat akan sangat kurang, stress dengan target kinerja yang harus dicapai, dan tidak bisa memberikan keteladanan di masyarakat karena keterbatasan jangkauan layanan. Hal ini sangat mungkin akan mempengaruhi capaian kinerjanya. Meskipun target IKD tercapai, namun di lapangan masih ada permasalahan sebagaimana disebutkan dalam hasil evaluasi RPJMD Kabupaten Temanggung pada tahun 2017, yaitu melemahnya daya dukung dan kemampuan penggerak program KB di masyarakat karena jumlah tenaga PLKB yang masih belum memenuhi standar kebutuhan, sehingga berakibat pula pada kurang optimalnya dukungan IMP karena keterbatasan PKB/PLKB untuk melakukan advokasi.

Kondisi PKB/PLKB di Kabupaten Temanggung bila diurai variabel permasalahannya, maka dapat dianalogikan dengan variabel dan hasil penelitian Rokhilah (2014), Lidia dan Hotlan (2017) bahwa motivasi berpengaruh positif pada kinerja. Penelitian Sulaiman (2014) bahwa self efficacymemberikan pengaruh positif dan signifikan terhadap kepuasan kerja, dan kepuasan kerja positif memediasi variabel bebas dengan variabel terikat secara parsial. Putu Eka Purnawa Dewi dan I Gusti Ayu Muati Dewi (2015) yang menyimpulkan bahwa self efficacy dan motivasi kerja berpengaruh pada kepuasan kerja secara simultan. Berdasarkan penelitian Didik Hadiyatno dan Wiwik Saraswati (2016), dengan kesimpulan bahwa self efficacy (keyakinan diri) dan kepuasan kerja memberikan pengaruh positif dan signifikan terhadap prestasi kerja. I Wayan Juniatara dan I Gede Riana (2015) menyimpulkan bahwa motivasi memberikan pengaruh positif pada kinerja dan kepuasan kerja, dan kepuasan kerja berpengaruh positif terhadap kinerja. Ariyanti (2016) menyimpulkan bahwa self efficacy dan motivasi berpengaruh positif dan kuat pada kinerja. M. Abdul Azis (2016) menyimpulkan dalam penelitiannya bahwa motivasi memberikan pengaruh signifikan terhadap kinerja melalui mediasi kepuasan kerja. Penelitian yang dilakukan oleh Afniyanti juga Nur Dwi Pujiyanto, Dyah Retna Puspita, dan Bambang Tri Harsanto (2017), 
menyimpulkan bahwa motivasi berpengaruh positif dan kuat pada Kinerja Penyuluh Keluarga Berencana. Penelitian Diyanti, Musa Hubeis, dan M. Joko Affandi (2017) menyimpulkan, bahwa motivasi kerja dan iklim kerja memberikan pengaruh signifikan terhadap kepuasan kerja Tenaga Kependidikan IPB, dan kepuasan kerja berpengaruh terhadap kinerja Tenaga Kependidikan IPB Kondisi permasalahan di lapangan dan juga adanya ketimpangan antara realitas dengan idelitas kondisi PKB/PLKB di DPPKBPPPA Kabupaten Temanggung, menjadi alasan bagi penulis untuk melakukan penelitian tentang "Pengaruh Self Efficacy dan Motivasi terhadap Prestasi Kerja Penyuluh Keluarga Berencana di Kabupaten Temanggung dengan Kepuasan Kerja sebagai Variabel Intervening."

Pertanyaan penelitian:

1. Bagaimana pengaruh self efficacy terhadap kepuasan kerja PKB?

2. Bagaimana pengaruh motivasi terhadap kepuasan kerja PKB?

3. Bagaimana pengaruh self efficacy terhadap prestasi kerja PKB?

4. Bagaimana pengaruh motivasi terhadap prestasi PKB?

5. Bagaimana pengaruh kepuasan kerja terhadap prestasi kerja PKB?

6. Bagaimana pengaruh self efficacy terhadap prestasi kerja PKB yang dimediasi oleh kepuasan kerja?

7. Bagaimana pengaruh motivasi terhadap prestasi kerja PKB yang dimediasi oleh kepuasan kerja?

Tujuan penelitian adalah:

1. Untuk mengetahui pengaruh self efficacy terhadap kepuasan kerja PKB.

2. Untuk mengetahui pengarumh motivasi terhadap kepuasan kerja PKB.

3. Untuk mengetahui pengaruh self efficacy terhadap prestasi kerja PKB.

4. Untuk mengetahui pengaruh motivasi terhadap prestasasi kerja PKB.

5. Untuk mengetahui pengaruh kepuasan kerja terhadap prestasi kerja PKB.

6. Untuk mengetahui pengaruh self efficacy terhadap prestasi kerja PKB yang dimediasi oleh kepuasan kerja.

7. Untuk mengetahui pengaruh motivasi terhadap prestasi kerja PKB yang dimediasi oleh kepuasan kerja.

\section{Manfaat penelitian:}

Penelitian ini diharapkan bermanfaat dalam memberikan informasi tentang pengaruh self efficacy dan motivasi terhadap prestasi kerja Penyuluh Keluargar Berencana yang dimediasi oleh kepuasan kerja. Juga mendukung dan menguatkan pembuktian teori dalam ilmu Manajemen Sumber Daya Manusia khususnya tentang self efficacy, motivasi, kepuasan kerja, dan prestasi kerja atau kinerja pegawai yang diharapkan menambah referensi untuk dikembangkan dalam penelitian berikutnya. Adapun bagi pemerintah dan masyarakat, hasil penelitian ini diharapkan menjadi masukan bagi masyarakat Kabupaten Temanggung untuk ikut peduli pada program KKBPK. Sedangkan bagi Pemerintah Kabupaten Temanggung hasil penelitian ini diharapkan menjadi masukan bagi penyusunan kebijakan terutama pemerataan SDM di lingkungan DPPKBPPPA dan kebijakan program pembangunan KKBPK yang terintegrasi dari semua sektor terkait baik pemerintah, swasta, dunia usaha, maupun masyarakat untuk saling bersinergi, sehingga memberikan motivasi kuat kepada PKB untuk memberikan dedikasi terbaiknya bagi pembangunan kependudukan di Kabupaten Temanggung. 


\section{KAJIAN PUSTAKA}

\section{Self Efficacy}

Self efficacy menurut Luthan (2005) adalah suatu kenyataan seseorang terkait kemampuan dirinya untuk melakukan tugas-tugas tertentu secara spesifik. Efikasi diri juga merupakan konsep diri dan berkaitan erat dengan persepsi seseorang terhadap kemampuan dan keahliannya dalam menghadapi suatu tugas tertentu.

Faktor-faktor yang berpengaruh terhadapself efficacy menurut Luthan (2005) adalah:

- kemampuan memecahkan masalah

- kemampuan melakukan hubungan dengan orang lain

- tingkat laku dalam lingkungan.

\section{Motivasi}

Motivasi merupakan proses yang memberikan doronganpada individu untuk melaksanakan rangkaian aktivitas untuk mencapai tujuan tertentu karena adanya kebutuhan-kebutuhan. Apabila tujuan berhasil dicapai akan memberikan kepuasandan kebutuhan-kebutuhan tersebut terpenuhi (Munandar,2001).

Aspek-aspek motivasi kerja menurut Munandar (2001) adalah sikap disiplin karyawan, imajinasi dan kemampuanmemadukan gagasanyang tinggi, kepercayaan diri, daya tahan terhadap tekanan, dan tanggung jawab dalam melaksanakantugas.

\section{Kepuasan Kerja}

Kepuasan kerja juga diartikan sebagai cerminan sikap karyawan terhadap pekerjaannya. Robbins \& Coulter (Khalid, dkk 2013) kepuasan kerja mengacu pada pendapat umum karyawan terhadap pekerjaannya, seperti orang yang memiliki tingkat kepuasan kerja yang tinggi, mempunyai perasaan positif terhadap pekerjaannya, sedangkan orang yang tidak puas dengan pekerjaannya akan memiliki sikap negatif.

Menurut Robbins (dalam widodo 2010), ada 5 faktor yang mendorong terciptanya kepuasan kerja, yaitu pekerjaan yang penuh tantangan, gaji atau imbalan, kondisi kerja, rekan kerja, dan kesesuaian pekerjaan.

\section{Prestasi Kerja}

Menurut Sutrisno (2011) prestasi kerja adalah hasil kerja yang telah diraih seseorang dalam melakukan aktivitas kerjanya, dan membuatnya bangga. Jadi prestasi diartikan sebagai tingkat kecakapan seseorang pada tugas-tugas yang dikerjakannyayang meliputi aspek-aspekhasil kerja, pengetahuan karyawan, kecekatan mental, inisiatif, sikap, dan disiplin waktu. 


\section{Model Penelitian}

Model penelitian ini adalah:

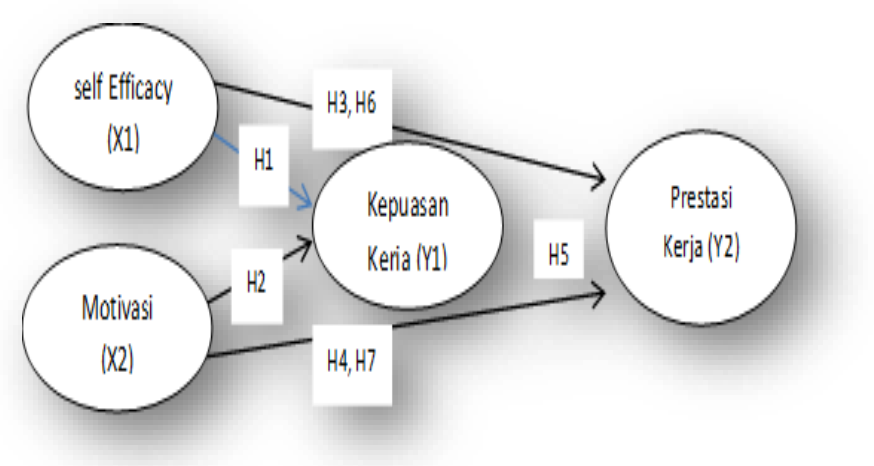

Gambar 1. Model Penelitian

\section{Pengembangan Hipotesis}

\section{Hubungan antara Dua Variabel atau Lebih}

Berdasarkan model penelitian tersebut, maka dirumuskan 7 hipotesis sebagai berikut:

a. H1: Self efficacy berpengaruh secara positif dan signifikan terhadap kepuasan kerja.

b. H2: Adanya pengaruh positif dan signifikan antara motivasi kerja dengan kepuasan kerja.

c. H3: Adanya pengaruh antara kepuasan kerja dengan prestasi kerja.

d. H4: Self efficacy berpengaruh positif dan signifikan terhadap prestasi kerja.

e. H5: motivasi berpengaruh positif dan signifikan terhadap prestasi kerja.

f. H6: Ada pengaruh positif self efficacy terhadap prestasi kerja PKB yang dimediasi oleh kepuasan kerja.

g. H7: Ada pengaruh positif motivasi kerja terhadap prestasi kerja yang dimediasi oleh kepuasan kerja.

\section{METODE PENELITIAN}

Penelitian ini dilaksanakan di Dinas Pengendalian Penduduk, Keluarga Berencana, Pemberdayaan Perempuan dan Perlindungan AnakKabupaten Temanggung. Populasi dalam penelitian ini adalah Penyuluh Keluarga Berencana (PKB) Kabupaten Temanggung sebanyak 43 orang.Pengambilan sampel menggunakan teknis sampling jenuh, yakni mengambil semua anggota populasi untuk sampel. Pengumpulan data berdasarkan sumber primer melalui kuesioner, dan sumber sekunder. Variabel independen dalam penelitian ini adalah self efficacy dan motivasi. Variabel dependen adalah prestasi kerja, dan variabel interveningnya adalah kepuasan kerja.

\section{Uji instrumen penelitian}

Uji Validitas, untuk mengetahui ketepatan alat ukur. Uji validitas menggunakan validitas isi, yaitu melihat apakah alat ukur telah memuat pernyataan yang relevan dengan materi penelitian. Uji validitas dalam penelitian ini menggunakan korelasi product moment. Hasil uji validitas yang dilakukan terhadap kuesioner self efficacy, motivasi, kepuasan kerja, dan prestasi kerja. 
Uji reliabilitas, ketepatan alat ukur, apakah suatu hasil pengukuran dapat dipercaya atau tidak. Instrumen dianggap baik jika mampu memberikan hasil yang kurang lebih sama pada beberapa kali pengukuran subjek yang sama dengan unsur yang diukur dalam subjek tersebut sama. Uji ini dilakukan dengan menggunakan rumus cronbach'c alpha, bila nilai alpha $(\alpha)>0,60$ maka alat uji dianggap reliabel.

Uji asumsi klasik, bertujuan untuk mendapatkan hasil yang terbaik, sebelum melakukan uji linear berganda (Ghozali, 2011). Pemenuhan asumsi klasik ini bertujuan agar variabel bebas sebagai estimator atas variabel terikat tidak bias. Uji asumsi klasik terdiri dari uji normalitas, uji multikoliniearitas, dan heteroskedastisitas.

Uji normalitas, untuk menguji apakah dalam sebuah model regresi, variabel terikat dan variabel bebas atau keduanya mempunyai distribusi normal atau tidak. Penggunaan model regresi untuk prediksi akan menghasilkan kesalahan (disebut residu), yaitu selisih antara data aktual dengan data hasil peramalan. Residu yang ada seharusnya berdistribusi normal. Model regresi yang baik adalah distribusi data normal atau mendekati normal.

Uji multikoliniearitas, untuk menguji apakah pada model regresi ditemukan adanya korelasi antar variabel bebas. Model regresi yang baik variabel-variabel bebas seharusnya tidak berkorelasi satu dengan yang lainnya, hal ini dapat dideteksi dengan melihat korelasi antar variabel bebas atau lewat angka VIF. Suatu model regresi dikatakan bebas dari multikolinieritas, jika mempunyai nilai VIF disekitar angka 1 dan/atau mempunyai angka tolerance mendekati 1 , dimana tolerance $=1 / \mathrm{VIF}$ atau bisa juga VIF $=1 /$ tolerance $($ Sugiono, 2011).

Uji heteroskedastisitas, untuk mengetahui apakah dalam model regresi terjadi perbedaan variance (variasi) dari nilai residual satu pengamatan ke pengamatan yang lain. Jika ditemukan varian dari nilai residual satu pengamatan ke pengamatan lainnya bersifat tetap, maka disebut homoskedastisitas, akan tetapi jika ditemukan varian dari nilai residual satu pengamatan ke pengamatan lainnya berbeda, maka disebut heteroskedastisitas. Model regresi yang baik semestinya tidak ada gejala heteroskedastisitas.

\section{Analisis Data}

Berdasarkan gambar model penelitian tersebut di atas, maka penelitian ini menggunakan paradigma jalur (Sugiyono, 2011). Dinamakan paradigma jalur karena terdapat variabel yang berfungsi menjadi jalur mediasi (Y1), yaitu kepuasan kerja sebagai variabel intervening. Dengan adanya variabel Y1, akan diketahui apakah untuk mencapai Y2 harus melewati variabel mediasi atau bisa langsung.Teknik analisis menggunakan analisis jalur (path analysis) dibantu dengan program SPSS 20, dan sobel test untuk uji mediasi. Tahapan dalam analisis ini adalah sebagai berikut:

- Pembuatan regresi model I, yaitu:

$\mathrm{Y} 1=\mathrm{a}+\beta 1 \mathrm{X} 1+\beta 2 \mathrm{X} 2+\mathrm{e} 1$

- Pembuatan regresi model II, yaitu:

$\mathrm{Y} 2=\mathrm{a}+\beta 1 \mathrm{X} 1+\beta 2 \mathrm{X} 2+\beta 3 \mathrm{Y} 1+\mathrm{e} 2$

- Uji Hipotesis dan Pembuatan Kesimpulan yang meliputi uji T, uji F, menghitung koefisen determinan, dan uji mediasi dengan sobel test.Sobelt Test dikenalkan oleh Sobel (1982) untuk menguji variabel mediasi (intervening). Uji ini bertujuan untuk mengetahui seberapa kuat pengaruh tidak langsung variabel bebas terhadap variabel terikat melalui variabel intervening (pengaruh $\mathrm{X}$ terhadap $\mathrm{Y}$ melalui $\mathrm{M}$ ). Pengaruh tidak langsung ini dihitung dengan cara mengalikan jalur X-M (a) dengan jalur M-Y (b) atau disebut jalur ab. Koefisien ab dihitung dengan rumus $a b=\left(c^{\prime}-c\right)$, dimana $c$ adalah pengaruh $X$ terhadap $Y$ tanpa mengontrol $M$, 
sedangkan c' adalah koefisien pengaruh X terhadap Y setelah mengontrol M. Standar error koefisien a dan b ditulis dengan Sa dan Sb. Besarnya standar error tidak langsung ditulis dengan Sab. Sab dihitung dengan rumus:

$\mathrm{Sab}=\sqrt{\mathbf{b 2 S a 2}+\mathbf{a 2 S b 2}+\mathrm{Sa2Sb2}}$

Keterangan:

$\mathrm{Sa} \quad$ : standar error koefisien a

$\mathrm{Sb} \quad$ : standar error koefisien $\mathrm{b}$

b : : koefisien variabel mediasi

a : kofisien variabel bebas

Untuk menguji signifikansi pengaruh tidak langsung, maka perlu menghitung nilai t dari koefisien ab dengan rumus:

$$
t=\frac{\mathrm{ab}}{S a b}
$$

Nilai t hitung dibandingkan dengan nilai $\mathrm{t}$ tabel. Jika nilai $\mathrm{t}$ hitung lebih besar dari nilai $\mathrm{t}$ tabel, maka kesimpulannya terjadi pengaruh mediasi (Ghozali, 2017).

\section{HASIL DAN PEMBAHASAN}

Uji Validitas:

Hasil uji validitas yang dilakukan terhadap kuesioner self efficacy, motivasi, kepuasan kerja, dan prestasi kerja diperoleh hasil sebagai berikut:

Tabel 2.Hasil Uji Validitas

Variabel Self Efficacy, Motivasi,

Kepuasan Kerja, dan Prestasi Kerja

\begin{tabular}{ccccc}
\hline \multirow{2}{*}{ No } & Variabel & Item & $\begin{array}{c}\text { Koefisien } \\
\text { Korelasi }\end{array}$ & Sig \\
& & Pertanyaan & (r) & \\
\hline 1 & Self & Pertanyaan 1 & 1 & 0,000 \\
& efficacy & Pertanyaan 2 & 0,663 & 0,000 \\
& & Pertanyaan 3 & 0,462 & 0,009 \\
& & Pertanyaan 4 & 0,800 & 0,000 \\
& & Pertanyaan 5 & 0,367 & 0,042 \\
& & Pertanyaan 6 & 0,508 & 0,004 \\
\hline 2 & Motivasi & Pertanyaan 1 & 1 & 0,000 \\
& & Pertanyaan 2 & 0,492 & 0,005 \\
& & Pertanyaan 3 & 0,605 & 0,000 \\
& & Pertanyaan 4 & 0,571 & 0,001 \\
& & Pertanyaan 5 & 0,535 & 0,002 \\
& & Pertanyaan 6 & 0,420 & 0,019 \\
& & Pertanyaan 7 & 0,464 & 0,009 \\
& & Pertanyaan 8 & 0,465 & 0,008 \\
& & Pertanyaan 9 & 0,401 & 0,025 \\
& & Pertanyaan 10 & 0,463 & 0,009 \\
& & Pertanyaan 11 & 0,472 & 0,007 \\
& & Pertanyaan 12 & 0,425 & 0,017 \\
\hline 3 & Kepuasa & Pertanyaan 1 & 1,000 & 0,000 \\
& n Kerja & Pertanyaan 2 & 0,700 & 0,006 \\
& & Pertanyaan 3 & 0,481 & 0,006 \\
\hline
\end{tabular}




\begin{tabular}{cccc}
\hline \multirow{2}{*}{ No Variabel } & $\begin{array}{c}\text { Item } \\
\text { Pertanyaan }\end{array}$ & $\begin{array}{c}\text { Koefisien } \\
\text { Korelasi } \\
\text { (r) }\end{array}$ & Sig \\
\hline \multirow{4}{*}{. Pertanyaan 4 } & 0,485 & 0,006 \\
& Pertanyaan 5 & 0,420 & 0,019 \\
& Pertanyaan 6 & 0,448 & 0,012 \\
& Pertanyaan 7 & 0,475 & 0,007 \\
& Pertanyaan 8 & 0,420 & 0,019 \\
& Pertanyaan 9 & 0,366 & 0,043 \\
& Pertanyaan 10 & 0,394 & 0,028 \\
& Pertanyaan 11 & 0,542 & 0,002 \\
\hline Kerja & Pertanyaan 1 & 1,000 & 0,000 \\
& Pertanyaan 2 & 0,674 & 0,000 \\
& Pertanyaan 3 & 0,603 & 0,000 \\
& Pertanyaan 4 & 0,625 & 0,000 \\
& Pertanyaan 5 & 0,441 & 0,013 \\
& Pertanyaan 6 & 0,385 & 0,033 \\
& Pertanyaan 7 & 0,411 & 0,022 \\
& Pertanyaan 8 & 0,542 & 0.002 \\
& Pertanyaan 9 & 0,462 & 0,009 \\
& Pertanyaan 10 & 0,422 & 0,018 \\
\hline Sumber: Data primer 2019, diolah & &
\end{tabular}

Sumber: Data primer 2019, diolah

Berdasarkan data pada Tabel 2 di atas pada masing-masing pertanyaan nilai koefisien korelasinya lebih besar dari nilai $\mathrm{r}(0,361)$, maka dapat disimpulkan bahwa item pertanyaan variabel self efficacy, motivasi, kepuasan kerja, dan prestasi kerja pada kuesioner adalah valid, layak digunakan sebagai alat ukur.

\section{Uji Reliabilitas}

Tabel 3.Hasil Uji Reliabilitas

Variabel Self Efficacy, Motivasi,

Kepuasan Kerja, dan Prestasi Kerja

\begin{tabular}{|c|l|c|c|}
\hline No & \multicolumn{1}{|c|}{ Variabel } & Alpha & Keterangan \\
\hline 1 & Self efficacy & 0,907 & Reliabel \\
\hline 2 & Motivasi & 0,934 & Reliabel \\
\hline 3 & Kepuasan kerja & 0,933 & Reliabel \\
\hline 4 & Prestasi kerja & 0,902 & Reliabel \\
\hline
\end{tabular}

Sumber: Data primer 2019, diolah

Uji ini dilakukan dengan menggunakan rumus cronbach'c alpha, bila nilai alpha $(\alpha)>0,60$ maka alat uji dianggap reliabel. Hasil uji reliabilitas sebagaimana Tabel 3menunjukkan bahwa semua indikator dalam variabel self efficacy, motivasi, kepuasan kerja, dan prestasi kerja adalah reliabel, sehingga semua item dalam kuesioner dapat digunakan sebagai alat ukur.

\section{Uji Asumsi Klasik}

\section{Uji Normalitas}

Berdasarkan hasil uji normalitas, didapatkan bahwa semua model regresi variabel self efficacy dan motivasi terhadap kepuasan kerja berdistribusi normal. Model regresi pengaruh self efficacy 
dan motivasi terhadap prestasi kerja berdistribusi normal Dan model regresi pengaruh kepuasan kerja terhadap prestasi kerja juga berdistribusi normal.

\section{Uji Multikoliniearitas}

Hasil uji multikoliniearitas menunjukkan bahwa angka VIF 1,580 untuk variabel self efficacy dan 1,580 untuk variabel motivasi jauh dari angka 1, juga angka tolerance 0,633 masih di bawah 1, hal ini menunjukkan dugaan tidak adanya gejala multikolinieritas, yaitu tidak ada hubungan antar variabel bebas.

\section{Uji Heteroskedastisitas}

Hasil uji Heteroskedastisitasmenunjukkan model regresi bebas dari gejala heteroskedasitas, dimana tidak ditemukan variasi dari nilai residual pengamatan satu ke pengamatan yang lain.

\section{Hasil analisis jalur}

\section{Analisis regresi linear berganda model I}

Rumus matematis analisis ini adalah:

$\mathrm{Y} 1=\mathrm{a}+\beta 1 \mathrm{X} 1+\beta 2 \mathrm{X} 2+\mathrm{e} 1$

Persamaan ini untuk melihat pengaruh variabel bebas self efficacy (X1) dan motivasi (X2) terhadap kepuasan kerja (Y1).Berdasarkan output SPSS 20 didapatkan nilai R Square 0,525 artinya 52,5\% kepuasan kerja bisa dijelaskan oleh variabel self efficacy dan motivasi. Koefisien regresi X1 sebesar -0,338, koefisien negatif berarti tidak ada hubungan searah antara self efficacy dengan kepuasan kerja. Sementara koefisien regresi X2 sebesar 0,878, ada hubungan searah antara motivasi dengan kepuasan kerja, dan sangat kuat. Hasil uji t menunjukkan nilai signifikansi $\mathrm{X} 1$ dan X2 lebih kecil dari 0,05, artinya variabel self efficacy dan motivasi berpengaruh signifikan pada kepuasan kerja.

\section{Pengujian hipotesis ke-1}

Hasil analisis ini menunjukkan bahwa hipotesis ke-1, yang menyatakan self efficacy berpengaruh secara positif dan signifikan terhadap kepuasan kerja, ditolak. Hal ini berbeda dengan hasil penelitian Sulaiman (2014), Purnawa Dewi dan Muati Dewi (2015) dan Ni made Sintya Dewi dan I Gede Adnyata (2016) yang menyimpulkan self efficacy berpengaruh positif dan signifikan terhadap kepuasan kerja.

\section{Pengujian hipotesis ke-2}

Berdasarkan hasil analisis, hipotesis ke-2 yang menyatakan bahwa adanya pengaruh positif dan signifikan antara motivasi dengan kepuasan kerja, diterima. Hasil penelitian ini sebagaimana kesimpulan para peneliti terdahulu seperti Kartika dan kaihatu (2010), Putu Eka dan I Made (2016), I Wayan Juniantara dan I Gede Riana (2015), M. Abdul Azis (2016), Diyanti, Hubeis, dan Joko (2017), juga Lidia dan Hotlan (2017), bahwa motivasi berpengaruh positif dan signifikan terhadap kepuasan kerja.

\section{Analisis Regresi Linear Berganda Model II}

Rumus matematis dalam analisis ini adalah:

$\mathrm{Y} 2=\mathrm{a}+\beta 1 \mathrm{X} 1+\beta 2 \mathrm{X} 2+\beta 3 \mathrm{Y} 1+\mathrm{e} 2$ 
Persamaan ini akan melihat pengaruh variabel bebas self efficacy (X1) dan motivasi (X2) terhadap prestasi kerja (Y2), dan pengaruh kepuasan kerja (Y1) terhadap prestasi kerja (Y2). Berdasarkan outpuT SPSS 20 didapatkan nilai $\mathrm{R}$ Square 0,641 artinya $64,1 \%$ variabel prestasi kerja bisa dijelaskan oleh variabel self efficacy, motivasi, dan kepuasan kerja. Hasil uji F menunjukkan nilai signifikansi 0,000 (lebih kecil dari 0,05) artinya secara bersama-sama self efficacy, motivasi, dan kepuasan kerja berpengaruh terhadap prestasi kerja. Hasil uji t menunjukkan nilai signifikansi self efficacy 0,797 (lebih besar dari 0,05) artinya self efficacy secara parsial tidak berpengaruh terhadap prestasi kerja. Nilai signifikansi variabel motivasi 0,001 (lebih kecil dari 0,05) artinya motivasi berpengaruh signifikan terhadap prestasi kerja. Sedangkan nilai signifikansi kepuasan kerja 0,762 (lebih besar dari 0,05) artinya kepuasan kerja tidak berpengaruh signifikan terhadap prestasi kerja.

\section{Pengujian hipotesis ke-3}

Berdasarkan hasil analisis ini menunjukkan bahwa hipotesis ke-3 yang menyatakan bahwa kepuasan kerja berpengaruh terhadap prestasi kerja, ditolak. Hal ini berbeda dengan penelitian terdahulu yang dilakukan oleh Juniantara dan Riana (2015), Abdul Azis (2016), Didik Hadiyatno dan Wiwik Saraswati (206), Diyanti, Hubeis, dan Joko (2017), Bayu dan Corry (2017), dan Rianto (2017) yang menyimpulkan bahwa kepuasan kerja berpengaruh signifkan pada pencapaian prestasi kerja atau kinerja karyawan.

\section{Pengujian hipotesis ke-4}

Berdasarkan hasil analisis,hipotesis ke-4 yang menyatakan bahwa self efficacy berpengaruh positif dan signifikan terhadap prestasi kerja ditolak. Hal ini berbeda dengan hasil penelitian Sulaiman (2014), Didik Hadiyatno dan Wiwik Saraswati (2016), Saryadi dan Istiyawati (2018), dan sugmawati dan Afriyanti (2018) yang berkesimpulan bahwa self efficacy memberikan pengaruh positif dan signifikan terhadap prestasi kerja karyawan. Penelitian mereka menunjukkan bahwa semakin tinggi self efficacy karyawan akan meningkatkan prestasi kerjanya.

\section{Pengujian hipotesis ke-5}

Berdasarkan hasil analisis, hipotesis ke-5 yang menyatakan bahwa motivasi berpengaruh positif dan sifnifikan terhadap prestasi kerja, diterima. Kesimpulan penelitian ini sebagaimana dikemukan oleh para peneliti terdahulu, Rokhilah (2014), Pujiyanti dkk (2017), Lidia dan Hotlan (2017), Jouita dkk (2016), Agita (2016) bahwa motivasi memberikan pengaruh positif dan signifikan terhadap prestasi kerja. Oleh karena itu organisasi perlu memberikan motivasi kepada PKB agar dapat mencapai prestasi kerja yang lebih baik.

\section{Analisis Pengaruh Variabel Mediasi}

\section{Analisis pengaruh X1 terhadap Y2 melalui Y1}

Berdasarkan hasil perhitungan diketahui bahwa pengaruh langsung adalah sebesar 0,038, sedangkan pengaruh tidak langsung sebesar-0,016224. Nilai pengaruh tidak langsung lebih kecil dari nilai pengaruh langsung, hal ini berarti pengaruh X1 terhadap Y2 melalui Y1 tidak signifikan. Dengan kata lain Y1 tidak berpengaruh sebagai variabel mediasi X1 terhadap Y2.

\section{Analisis pengaruh X2 terhadap Y2 melalui Y1}

Berdasarkan hasil perhitungan diketahui bahwa pengaruh langsung adalah sebesar 0,734, sedangkan pengaruh tidak langsung sebesar 0,042144. Nilai pengaruh tidak langsung lebih kecil dari nilai pengaruh langsung, hal ini berarti pengaruh X2 terhadap Y2 melalui Y1 tidak signifikan. Dengan kata lain Y1 tidak berpengaruh sebagai variabel mediasi X2 terhadap Y2. 


\section{Uji sobel}

\section{Pengujian hipotesis ke-6}

\section{Uji sobel pengaruh self efficacy terhadap prestasi kerja melalui kepuasan kerja}

Berdasarkan hasil uji sobel Nilai t hitung 0,11721 lebih kecil dari t tabel dengan tingkat signifikansi 0,05 , yaitu 1,68595. Hipotesis ke-6 yang menyatakan self efficacy berpengaruh terhadap prestasi kerja dengan dimediasi oleh kepuasan kerja ditolak. Artinya kepuasan kerja tidak mampu memediasi pengaruh self efficacy terhadap prestasi kerja.

\section{Pengujian hipotesis ke-7}

\section{Uji sobel pengaruh motivasi terhadap prestasi kerja melalui kepuasan kerja}

Nilai t hitung 0,33097 lebih kecil dari t tabel dengan tingkat signifikansi 0,05, yaitu 1,68595.Sehingga dapat disimpulkan bahwa hipotesis ke-7 yang menyatakan motivasi berpengaruh terhadap prestasi kerja dengan dimediasi oleh kepuasan kerja ditolak. Artinya kepuasan kerja tidak mampu memediasi pengaruh motivasi terhadap prestasi kerja.

\section{KESIMPULAN DAN SARAN}

Berdasarkan hasil pembahasan di atas, dapat disimpulkan jawaban atas hipotesis penelitian ini sebagai berikut:

a. Self efficacy tidak berpengaruh terhadap kepuasan kerja PKB. Jadi kepuasan kerja PKB tidak dipengaruhi oleh tingkat self efficacy yang dimilikinya.

b. Motivasi berpengaruh positif dan signifikan terhadap kepuasan kerja. Hal ini mengindikasikan bahwa untuk mendapatkan kepuasan kerja, motivasi sangat dibutuhkan oleh PKB. Oleh karenanya organisasi perlu memberikan motivasi yang lebih baik bagi PKB. Semakin tinggi motivasi PKB, semakin tinggi pula tingkat kepuasan yang dirasakan.

c. Kepuasan kerja tidak berpengaruh terhadap prestasi kerja. Hal ini menunjukkan bahwa prestasi kerja PKB tidak dipengaruhi oleh tingkat kepuasan kerjanya.

d. Self efficacy tidak berpengaruh signifikan terhadap prestasi kerja PKB.

e. Motivasi berpengaruh positif dan signifikan terhadap prestasi kerja PKB. Hal ini mengindikasikan bahwa untuk meraih prestasi kerja yang tinggi, dibutuhkan motivasi yang tinggi. Oleh karena itu organisasi perlu memberikan motivasi kepada PKB agar dapat mencapai prestasi kerja yang lebih baik.

f. Kepuasan kerja tidak memediasi pengaruh self efficacy terhadap prestasi kerja PKB. Hal ini menunjukkan bahwa kepuasan kerja tidak ada kaitannya dengan peningkatan self efficacy maupun prestasi kerja PKB.

g. Kepuasan kerja tidak memediasi pengaruh motivasi terhadap prestasi kerja PKB. Hal ini juga menunjukkan bawha kepuasan kerja tidak ada kaitannya dengan peningkatan motivasi dan prestasi kerja PKB. 


\section{DAFTAR PUSTAKA}

AA., Agitha, (2016) "Pengaruh Kepuasan Kerja, Motivasi, dan Komitmen Organisasi terhadap Kinerja Perawat pada Rumah Sakit Umum di Kota Bandung”, Tesis Sekolah Pascasarjana IPB, 2016.

Abdul Azis M., 2016. "Pengaruh Motivasi Kerja, disiplin Kerja dan Lingkungan Kerja terhadap Kinerha Melalui Kepuasan Kerja Para Pegawai Puskesmas Balapulang Kabupaten Tegal.” Multiplier, vol. 1 No. 1, November 2016.

Afriyanti, TW., Sugmawati, D., (2018) "Pengaruh Self Efficacy terhadap In-Role Performance Karyawan dengan Motivasi Kerja sebagai Variabel Moderator”, Jurnal Administrasi bisnis (JAB) Vol. 61, No. 4, Agustus 2018).

Anoraga, Panji, (2009) Psikologi Kerja, Rineka Cipta, Jakarta.

Ariyanti, (2016) "Kinerja Petugas Lapangan Keluarga Berencana (PLKB) di Desa Pakawa Kecamatan Pasangkayu Kabupaten Mamuju Utara", E-Jurnal Katalogis, Col.4, No. 4, April 2016).

Bandura, A, (1997), Self Efficacy, The Exercise of Control, W.H. Freeman and Company, New York.

Bappeda Temanggung, (2018) Evaluasi RPJMD Tahun 2017.

Bayu Dwi Laksono dan Corry Yohana, 2017. "Pengaruh Motivasi dan Lingkungan Kerja terhadap Kinerja Karyawan, dengan Kepuasan Kerja sebagai Variabel Mediasi pada PT. BNI Lifeinsurance” Jurnal Pendidikan Ekonomi dan bisnis (JPEB) Vol.5 1 Maret 2017.

BKKBN Perwakilan Jawa Tengah, (2019) Bahan Rakor Pembangunan Kependudukan, Keluarga Berencana, dan Pembangunan Keluarga.

BKKBN, (2015) Renstra BKKBN 2015-2019.

Dewi, Purnama, Dewi, Manuarti, (2015) "Pengaruh Self Efficacy Dan Motivasi Kerja Pada Kepuasan Kerja Karyawan Happy Bali Tour \& Travel Denpasar”, Jurnal Manajemen, Strategi Bisnis dan Kewirausahaan, Vol. 9, No.1, Februari 2015.

Diyanti, Hubeis, M., Affandi, (2017) "Pengaruh Motivasi Kerja dan Iklim Kerja Terhadap Kepuasan Kerja dan Implikasinya Terhadap Kinerja Tenaga Kependidikan Institut Pertanian Bogor”, Jurnal Aplikasi Bisnis dan Manajemen, Vol. 3, No. 3, September 2017).

Edy, Sutrisno, (2011) Manajemen Sumber Daya Manusia, Kencana, Jakarta.

Ghozali, Imam., 2017, Model Persamaan Struktural Konsep dan Aplikasi dengan Program AMOS 24, Edisi 7, Semarang, BP UNDIP.

I Wayan Juniatara, I Gede Riana, 2015. "Pengaruh Motivasi dan Kepuasan Kerja terhadap Kinerja Karyawan Koperasi di Denpasar." E-Jurnalekonomi dan bisnis Universitas Udayana 4.09 (2015).

Jouita Victoria Pattynama, Christoffel Kojo, dan Agusta L. Repi, 2016. "Pengaruh Motivasi Kerja, Disiplin Kerja, dan Kepemimpinan terhadap Prestasi Kerja Pegawai Di Badan Perpustakaan Provinsi Sulawesi Utara. Jurnal EMB Vol. 4 No. 1 Maret 2016.

Lidia Lusri dan Hotlan Siagian, 2017. "Pengaruh Motivasi Kerja terhadap Kinerja Karyawan Melalui Kepuasan Kerja sebagai Variabel Mediasi pada Karyawan PT. Borwita Citra Prima Surabaya. " Jurnal Agora vol.5 No.1, 2017. 
Luthans, F. (2014). Organizatonal behavior. Singapore: Mcgraw Hill Book co.

Munandar, A.S. (2001). Psikologi Industri dan Organisasi. Jakarta: Universitas Indonesia (UI-Press).

Ni Made Sintya Dewi dan I Gede Adnyana Sudibya, 2016. "Pengaruh Efikasi Diri terhadap Orgazational Citizenship Behavior dengan Kepuasan Kerja sebagai variabel Mediasi.” E-Jurnal Manajemen Unud, Vol. 5, No. 11, 2016.

Nur Dwi Pujiyanto, Dyah Retna Puspita, dan Bambang Tri Harsanto, 2017. "Pengaruh Kompetensi, Motivasi, Lingkungan Kerja, dan Persepsi Gaya Kepemimpinan terhadap Kinerja PenyuluhKeluargaBerencana."Masyarakat, Kebudayaan dan Politik Vol.30, No. 3, tahun 2017.

Pulungan, Nurmadhiyah, 2017. "Pengaruh Beban Kerja, Kepuasan Kerja, dan Komitmen Organisasi terhadap Kinerha Pemeriksa BPK RI Perwakilan Provinsi Lampung. “ Tesis Program Pasca sarjana Magister Manajemen Universital Lampurng, 2017.

Raharjo, Sahid (2014) "Cara uji Analisis Jalur (Path Analisys) dengan SPSS Lengkap", tersedia di www.spssindonesia.com (diakses 30 Juli 2019).

Raharjo, Sahid (2014) "Uji Validitas dan Reliabilitas", tersedia di www.spssindonesia.com (diakses 30 Juli 2019).

Robbins, Stephen, (2017) Perilaku Organisasi Edisi 16, Salemba Empat, Jakarta.

Rokhilah, 2014. "Pengaruh Kompetensi, Motivasi, dan Lingkungan Kerja terhadap Kinerja Penyuluh Lapangan Program Keluarga Berencana (PLKB) di Kabupaten Pemalang." Media Ekonomi dan Manajemen Vol. 29 No. 1 Januari 2014.

Sugiyono, (2011) Metode Penelitian Kuantitatif Kualitatif dan R \& D, Alfabeta, Bandung.

Sulaiman, 2014. "Pengaruh Pemberdayaan, Self Efficacy, dan Budaya Organisasi terhadap Kineeja Karyawan PT. Surya Madistrindo Cabang Lhokseumawe dengan Kepuasan Kerja sebagai Variabel Intervening." Jurnal Ekonomi, Manajemen dan Akuntasi Vol 4 N0. 1, Juni 2014. 